\title{
Evaluation of the Potential Energy from Wave Motion on the Sicilian coast
}

\author{
Alessia Viola, Marco Trapanese, Vincenzo Franzitta, \\ Dipartimento di Energia, Ing. Informazione, Mod. Matematici \\ Palermo University \\ Palermo, Italy \\ alessia.viola@unipa.it \\ marco.trapanese@unipa.it \\ franzitta@dream.unipa.it
}

\begin{abstract}
The purpose of this articles is quantitatively evaluate the wave climate variations of the northern Sicilian coasts. In particular, the objective of the study is Castellammare del Golfo, a marine site between Trapani and Palermo. In particular in this research, the wave energy of the Sicily has been studied by an analysis of wave data carried out in a 10- year period, using the measurements of buoyant of RON. The northwestern and southern coasts of Sicily have a lower potential with average wave power ranging between 2.5 and $6.5 \mathrm{~kW} / \mathrm{m}$.
\end{abstract}

Keywords—seaeave; energy; wave motion.

\section{INTRODUCTION}

Sicily (Italy) is the largest island in the Mediterranean Sea and the use of wave energy is developing. Wave energy represents the "new entry" in the extensive green energy discussion and has been recognised by the international community as a renewable energy source with the potential to contribute to the electricity market[1-3]. The definition of the potential energy of optimal coastal sites is one of the basic needs for the diffusion of new technologies and for their insertions. The entity of the wave energy source is the primary information required for launching a new wave power programme.[4-6]

Considerable works have been undertaken on wave energy assessment in several areas of the European coastline. The total wave power was found to range from $1 \mathrm{GW}$ in Sweden, to $120 \mathrm{GW}$ in UK, passing through $3.4 \mathrm{GW}$ of Denmark, $10 \mathrm{GW}$ in Portugal, $21 \mathrm{GW}$ in Ireland and over $28 \mathrm{GW}$ in the area of Gulf of Gascoigne, France.[1] Recent works focused on the Spanish coastline reveal an enormous potential in several coastal areas facing the Atlantic, with a wave power which frequently reaches $200 \mathrm{MWh} / \mathrm{m}$ and exceeds $400 \mathrm{MWh} / \mathrm{m}$ along the Death Coast.

Considering further the potential of other countries as Belgium, Germany and the Netherlands (for which no assessment is available), Pontes et al] assign an annual deep water resource of about $290 \mathrm{GW}$ for the Atlantic wave front area. On the Mediterranean side, the wave energy resource contribution from Spain, France, Italy and Greece is estimated to be $30 \mathrm{GW}$ [1].

The possibility to extract energy from the waves of the sea is encouraging the development of different electrical devices.
There are different types of wave energy converters. Some convert the wave energy into mechanical or hydraulic energy and after into electric energy. Others perform the direct conversion from waves to electrical energy. One of the latter devices is the point absorber.[3]

Although the sea can be considered an "infinite" resource of energy, the high cost of the design and realization of device is a is limit to the development of this new technology [7]

In the last July the Italian government established new incentive mechanisms: among the plants that will go directly to incentives also includes marine plants of limited power to $60 \mathrm{~kW}$; marine plants higher power, but limited to $5 \mathrm{MW}$, will have access to incentives has been entered in a special register (as showed in Fig. 1)

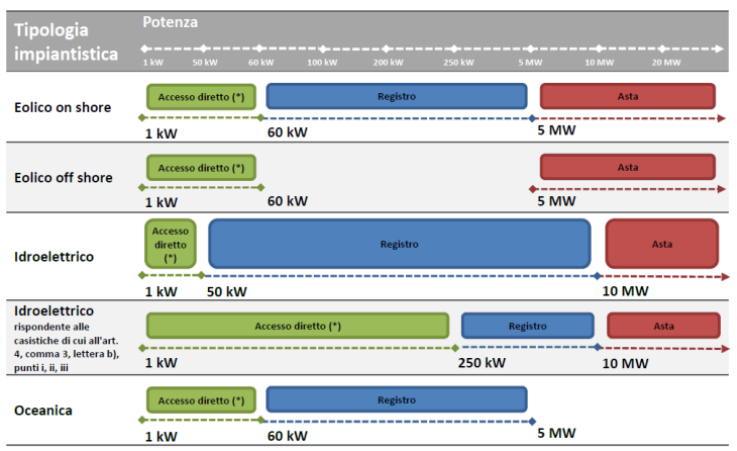

Fig. 1 The incentive mechanisms of DM 06/07/12

The definition of the potential energy of optimal coastal sites is one of the basic needs for the diffusion of new technologies and for their insertions. The determination of available wave energy potential of a given area is the basic requirement in any wave-energy program. Mostly, it is difficult to find spectral measurements of wave heights and periods due to economic and technical restrictions. For the reason that basic wave statistics is needed for a wave energy study, one can invoke alternate means to estimate the available wave energy[8-9].

The objective of this work is to define the energy potential in Sicilian coast using $t$ wave data; in fact the statistical analysis provides the use of data of RON to evaluate the wave energy potential in the site of Castellammare del Golfo, (town near Palermo) where will be installed a new electrical device. 


\section{Measure of WAVE EnERGy}

\section{A. Data availability of RON wave buoys}

The measurements used to the simulation come from Rete Ondametrica Nazionale (RON), an Italian Wave measuring Network managed by Institute for Environmental Protection and Research (ISPRA).

RON was born in 1989 and it's made by 8 directional buoys "datawell-wavec". These are in operation since recording significant wave height $H_{s}$, peak period $T_{p}$, mean period $\mathrm{T}_{\mathrm{m}}$ and mean wave direction $\theta_{\mathrm{m}}$. Until 2002 wave parameters were normally recorded every $3 \mathrm{~h}$ [10-11].

The network consists of 15 oceanographic buoys located along the Italian coast. The buoys are moored in fixed positions shown on charts in areas off-limits to fishing and navigation typically with a radius of about 250 meters. Each buoy (Axys Watchkeeper) has a diameter of 1.7 meters and a height on the waterline of 2.8 meters. It contains a wave meter directional accelerometer solid state, high precision, TRIAXYS[12].

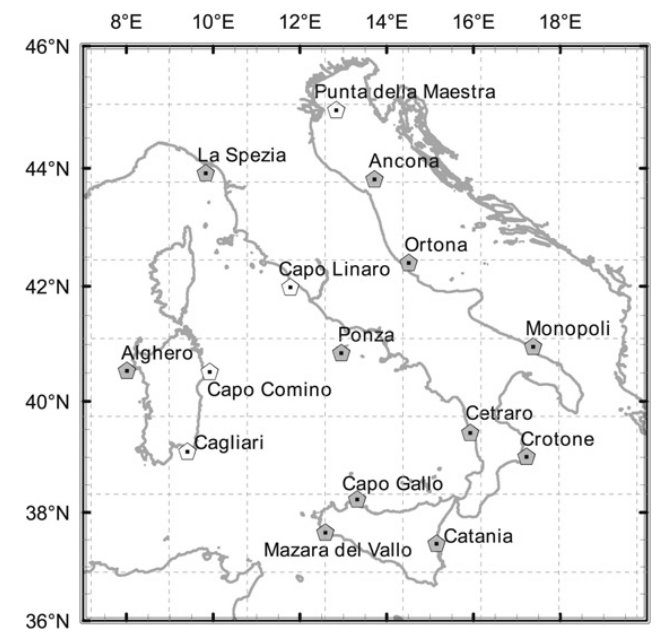

Fig. 2. Locations of RON wave buoys.[2]

\section{B. Wave parameters}

The main parameters used for the simulations are the period $\left(\mathrm{T}_{\mathrm{e}}\right)$ and the height of wave $\left(\mathrm{H}_{\mathrm{s}}\right)$. In fact, the buoys as almost all other stations located off the Italian coast, don't supply directly the energy period, so there are different mathematical relations that connect $\mathrm{T}_{\mathrm{e}}$ with mean period $\mathrm{T}_{\mathrm{m}}$.

In this study the expression used is:

$$
T_{e}=\alpha T_{p}
$$

where $\alpha$ depends on the shape of the spectrum waveform associated with samplings and its value is 0.9 while $T_{p}$ is the peak period.

As regards the value of $\mathrm{H}_{\mathrm{s}}$ is obtained by:

$$
H_{\frac{1}{3}}=\frac{1}{\frac{n}{3}} \sum_{j=1}^{\frac{n}{3}} H_{j}
$$

The estimation of wave power transmitted per unit width is represented below (adopted in in deep water, when the depth is greater than half the wavelength):

$$
P=\frac{\rho g^{2}}{64 \pi} H_{s}^{2} T_{e} \quad[\mathrm{~W} / \mathrm{m}]
$$

where $\rho$ is a seawater density and its value is, approximately, $1025 \mathrm{~kg} / \mathrm{m}^{3}$.

\section{Methods to Evaluate the Potential ENERGY}

Different wave measuring network can report on the status of the sea that is known sites where the buoys are installed.

Anyway the knowledge of the wave motion of big area outside of the measuring system is necessary to convert the mechanical energy in electric (energy) [13].

The aim of this work is to realize a mathematical tool .

The idea was born from the need to know the status of the sea of an unknown site where will be installed a new electric device.

The site is located within a geographical mesh note, that is surrounded by buoys measure for sites not too far away spatially. In particular the have some informations:

- $\quad$ to know of long measurement sampling ;

- $\quad$ to find a geographical mesh;

- to calculate the distance among wave note site and our unknown.

In the next section will be described a case study.

\section{CASE STUDY}

In the first part of the experimental study is been necessary to validate the correlation of buoys of RON that are inside chose geographical mesh. The buoys are: Cetraro, Ponza, Mazara del Vallo, Siniscola (Capo Comino) e Capo Gallo ( as showed in Fig.3). 


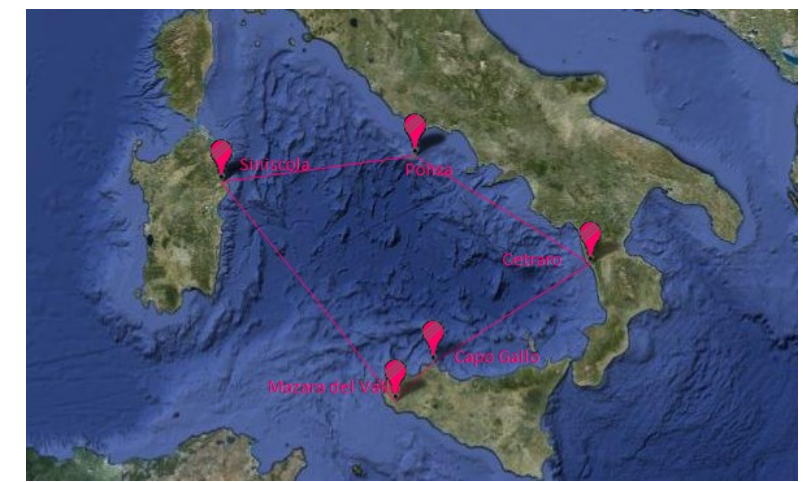

Fig. 3. Geographical mesh used and locations of 5 buoys.

The next step is to chose the period that will be used to statistical simulation.

In general, available times of five buoys are:

- Cetraro, 01/01/1999 to 05/04/2008;

- $\quad$ Ponza, 01/07/1989 to 31/03/2008;

- Mazara del Vallo, 01/07/1989 to 04/07/2008;

- $\quad$ Siniscola, $01 / 01 / 2004$ to $12 / 09 / 2005$;

- $\quad$ Capo Gallo, 01/01/2004 to 31/12/2008.

As for the climatic conditions, they influence powerfully the state of wave motion, so in the study it's necessary to chose four different period ( one for each season) of one significant year [14].

Based on the data, immediately after the filtering step (to eliminate hot spot), it was decided therefore to analyze the following ranges:

- $21 / 03 / 2004$ to $24 / 04 / 2004$ for the Spring ;

- $20 / 07 / 2004$ to $20 / 08 / 2004$ for the Summer;

- $20 / 10 / 2004$ to $20 / 11 / 2004$ for the Autumn;

- $20 / 02 / 2004$ to $20 / 03 / 2004$ for the Winter.

After many simulations, setting a period occurred as the value of the wave of a single buoy is always proportional to the other.

In particular, there has been a certain constancy in the relationship between the value of the single $\mathrm{H}_{\mathrm{m} 0 \mathrm{i}}$ buoy at fixed period, and the summation of the values of $\mathrm{H}_{\mathrm{m} 0 \mathrm{j}}$ stations remaining the same period.

It is expressed by the parameter $\mathrm{P}_{\mathrm{i}}(\mathrm{t})$ given by:

$$
P_{i}(t)=\frac{H(t)_{m 0 i}}{\sum_{j=1}^{n} H(t)_{m 0 j}}
$$

The second part of the study is addressed to obtain the value of $\mathrm{Hm}_{0}$ of the site "Castellammare del Golfo". A
Sicilian town among Palermo and Trapani where will be installed the buoy projected by University of Palermo.

It was possible to calculate the wave height at the site in question while having no device of measuring placed there. It has in fact worked the following relationship:

$$
H_{\text {castellamare }}(t)=M(t) \sum_{j=1}^{n} H(t)_{m 0 j}
$$

where $\mathrm{M}(\mathrm{t})$ is a parameter obtained by weighted harmonic mean expressed by:

$$
M(t)=\frac{\sum_{j=1}^{n} d_{j}}{\sum_{j=1}^{n} \frac{d_{j}}{P(t)_{j}}}
$$

where $d_{j}$ is the distance of the $j$-th buoy from the site in question and $\mathrm{P}(\mathrm{t}) \mathrm{j}$ is the parameter defined above (eq. 4).

\section{RESULTS}

As regards the results, we obtain values of $\mathrm{H}_{\text {mo }}$ of Castellamare del Golfo that change in function of the season.

As showed in the figure above.

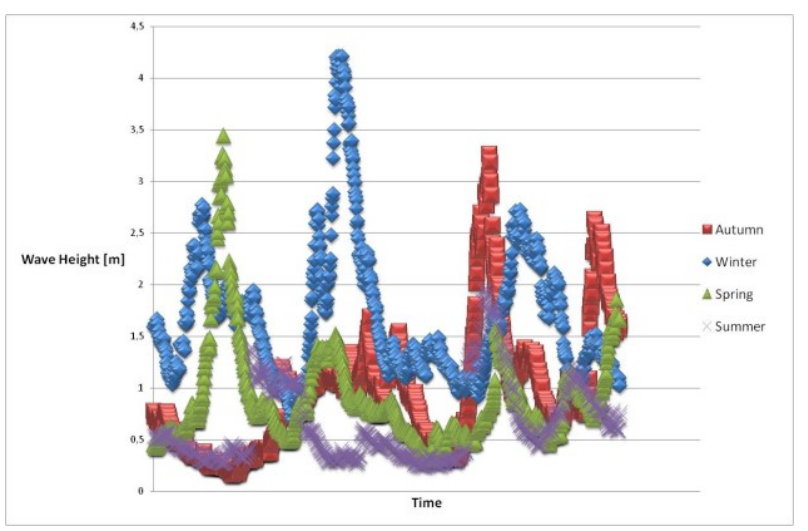

Fig. 4 .Trend of average height of Castellammare del Golfo

Using the eq.(3), it's possible to calculate the energy potential of the examined site. In the TABLE I we report the values.

TABLE I. ENERGY POTENTIAL OF THE CHOSEN SITE

\begin{tabular}{|l|c|c|}
\hline \multicolumn{3}{|c|}{ Castellammare del Golfo } \\
\hline \multicolumn{1}{|c|}{ Season of 2004 } & Wave Height & SI \\
\hline Spring & 2.7 & {$[\mathrm{~kW} / \mathrm{m}]$} \\
\hline Summer & 1.1 & {$[\mathrm{~kW} / \mathrm{m}]$} \\
\hline Autumn & 2.75 & {$[\mathrm{~kW} / \mathrm{m}]$} \\
\hline Winter & 5.1 & {$[\mathrm{~kW} / \mathrm{m}]$} \\
\hline
\end{tabular}


We note immediately that, as might be expected, the wave climate vary significantly with the seasons and that summer is the season that presents a potential for extracting less, or less than half of the fall term and nearly one fifth of the wintry

\section{Conclusions}

In conclusion, this work confirmed our interest to the chose site. The simulation showed as in the winter or autumn, could may occur the particular conditions of wave motion which could be used by the electrical device at the design stage. Obviously, the continuation of this work will be based on the comparison among the results obtained by statistical calculation and real wave data obtained by the installation of buoys (projected by University of Palermo).

\section{AcKnowledgment}

This work was funded by Ministero dell` Ambiente e del Mare through IMPETUS project.

\section{REFERENCES}

[1] Vicinanza D., Contestabile P., Ferrante V., "Wave energy potential in the north-west of Sardinia (Italy)" Renew Energ, vol. 50, , pp 506-521, February 2013.

[2] Liberti L., Carillo A., Sannino G., "Wave energy resource assessment in the Mediterranean, the Italian perspective" Renew Energ, vol 50", , pp 938-949, February 2013.

[3] Mendes R.P.G., Calado M.R.A., Mariano S.J.P.S., "Wave energy potential in Portugal-Assessment based on probabilistic description of ocean waves parameters" Renew Energ, vol 47, , pp 1-8, November 2012.

[4] Bonanno A., Franzitta V., Muzio F.P., Trapanese M., "A multiphysics approach to the design of a seawave energy conversion system", Proceedings of ICSET, Singapore, ,p.p. 665-668,art. no. 4747090, 2008.

[5] Franzitta V., Rizzo G., "Renewable energy sources: A mediterranean perspective", Proceedings ICBEE 2010-2nd International Conference on Chemical, Biological and Environmental Engineering, , p.48-51, art. no. 5652332 (2010).

[6] Di Dio V., Franzitta V., Muzio F., Scaccianoce G., Trapanese M., "The use of sea waves for generation of electrical energy and hydrogen". MTS/IEEE Biloxi - Marine Technology for Our Future: Global and Local Challenges, OCEANS, 2009, art. no. 5422319.

[7] Sorrentino G., Scaccianoce, G., Morale, M., Franzitta, V., "The importance of reliable climatic data in the energy evaluation", Energy Volume 48, Issue 1, pp74-79, December 2012.

[8] Trapanese M., Viola A., Franzitta V. , "Description of hysteresis of nickel metal hybride battery". IECON 2012, 38th Annual Conference on IEEE Industrial Electronics Society, Montreal, Canada, pp. 967-970.

[9] Franzitta V., Viola A., Trapanese M., "Description of hysteresis in Lithium battery by classical Preisach model", Advanced Materials Research Vols. 622-623, pp 1099-1103, 2013.

[10] Ciulla G., Franzitta V., Lo Brano V., Viola A., Trapanese M., "Mini Wind Plant to Power Telecommunication Systems: a Case Study in Sicily", Advanced Materials Research Vols. 622-623 pp 1078-1083, 2013.

[11] Trapanese M., "A model of a linear synchronous motor based on distribution theory", J App Phys, vol.111, Article number07E731, 1 April 2012.
[12] Trapanese M, "Noise enhanced stability in magnetic systems", J. App. PhysVolume 105, Issue 7, Article number 07D313, 2009.

[13] Cirrincione M., Miceli R., Galluzzo G.R., M. Trapanese," Preisach function identification by neural networks", IEEE Transactions on Magnetics Volume 38, Issue 5 I,pp 2421-2423, 2002.

[14] Trapanese M.; Franzitta V., Viola A. "The Jiles Atherton Model for Description Of Hysteresis in Lithium Battery" Conference Proceedings - IEEE Applied Power Electronics Conference and Exposition - APEC 2013- Long Beach,(CA), March 2013-978-1-4673-4355-8, pp 27732775 . 
